\title{
The Effectiveness of Designing Interactive Educational Software to Develop Instructional Design Skills among Students Teachers at Al Baha University
}

\author{
By \\ Dr. Abdullah K Alodail
}

\section{INTRODUCTION}

Many instructors at universities around the world have recently become interested in developing educational strategies to develop students' performance by using educational software in learning. This is because educational software can be utilized to educate individuals how to discover stories in the data, and how to visually communicate and share them with the audience effectively.

Teaching is a process that requires teachers to plan and make decisions about classroom practices, and teachers often rely on their beliefs and professional knowledge to guide them (Berthelsen, Brownlee \& Lewis, 2002).

According to Reiser and Dempsey (2007), the ADDIE instructional design model has five steps that are traditionally used by instructional designers and training developers: investigation, plan, progress, application, and assessment. One criticism of the ADDIE model is that it is more of a generic process and not as thorough as a Kemp model. Yet, there have been ample studies to show this particular instructional design model is useful. In short, the ADDIE design model is superior and should be used as a primary source.

Saraya (2009) discussed the fact that software is one of the most important forms of technology in the field of educational technology. Educational software is a successful way to educate students; because of achieving the objectives of the educational process.

Dr. Abdullah K Alodail, Assistant Professor, Faculty of Education, Baha University 
مجلة كلية التربية بالإسماعيلية - العدد الواحد والأربعون - مايو 1 I ـ

According to Vaughan (2011), multimedia can be considered as a set of animation, graphics, texts, sound, and video in numeral arrangement, and when the user has some control over what is offered, it will be interactive multimedia. However, multimedia is not always cooperative, for example, when a student press enters to move to the next screen in a linear fashion. Although, the task becomes interactive when the student affects what they see, for example, if their answer to the question determines which screen appears afterwards.

According to Liping (2017) educational software brings many benefits to students as it involves more than one sense in the learning process. The more learning channels the student uses, the greater the experience and knowledge acquired by the learner. Hence, the use of software is important in teaching, because by using a multimedia approach, learners can gain knowledge in an interesting way. Also, software can help learners identify their individual differences, which addresses and solves many educational problems. So, this kind of webbased multimedia teaching model has wide application prospects and needs to be further promoted.

The researcher reviewed the literature related to the use of interactive educational software on students' design skills in terms of instructional design. It is important to implement the new teaching methods in the educational environment to attract learners to use interactive educational software. Interactive educational software has affected students' skills in term of the development of some instructional design, because visual information is more effective at delivering a message than verbal or written forms. The researcher seeks to improve students' skills by using interactive educational software in the classroom to teaching students some instructional design skills. The important thing to bear in mind when using the software is to present image and word together including suitable colors, and forms. In that way, learners can deal with visual data successfully. Motivation theory supports software use during the educational process, because students are motivated to learn and pay attention.

The computer unit in education has been selected in order to verify the effectiveness of teaching with this method. The decision to focus on the subject of computers in special education was made because the material covered on this course is suitable for being taught using software design (interactive media), and it is therefore possible to 
measure the development of some instructional design skills among students at the College of education at Al-Baha University.

PROBLEMS WITH THE STUDY

Although various studies have discussed the impact of interactive educational software. Few have been conducted in Saudi Arabia. Investigating ways to improve students' skills at the College of Education at Al-Baha University could therefore fill a gap in the literature. The researcher conducted a pilot study to determine any problems related to carrying out the study by giving students a test to measure their knowledge of instructional design skills. Students' grades were low between $35-50 \%$ of deigning skills test which prompted the researcher to use modern technology (educational software) to develop their design skills. The decision was made to use ADDIE, as it is more comprehensive than other instructional design models, and therefore more beneficial for students and teachers in the twenty-first century. The model allows students to think and improve their design skills individually, whilst also allowing them to be creative.

According to Jhurree (2005), information and communication technology (ICT) can help reform educational settings in both rich and poor countries. For this reason, ICT needs to replace traditional forms of instruction in the educational environment. Technology motivates learners to study and makes teaching easier and more attractive for teachers. Developed countries tend to have more resources, knowledge, experience, and skills than developing countries, with the latter lacking adequate technical assistance and teacher preparation.

Mndzebele (2013) looked at the use of ICTs in schools in Swaziland and found that teachers there lacked ICT knowledge, had no technical aids, no Internet connectivity, no financial support, and no time available to them to develop these skills, despite the fact that technology helps learners' study more effectively and many schools use various educational technologies.

Abdullah (2017) looked at improving interactive software employed in the teaching of science among elementary students. The ADDIE instructional design model was used as a guideline for creating the interactive software. The study tool involved interviewing 10 experts about the software abilities used in science processing skills. The results revealed that the interactive software being used was able to effectively teach science processing skills to the elementary school learners. In future, it is hoped that a great deal more interactive software can be developed to help teach science to learners in schools. 


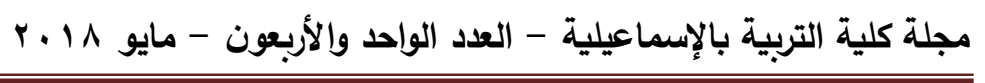

As interactive software has been shown to make learning science more interesting. In addition, it can be used both in and outside the classroom as teaching and learning aids.

Based on the researcher's experience working as a faculty member at the Faculty of Education for Boys at the University of Baha since 2013, it has become clear that there is a problem in the design skills of students. This is because of the obstacles facing students when learning how to use design instructional models.

The researcher identified a low level of skills among students, in terms of their ability to learn instructional design in education, largely due to the traditional teaching method used to teach these skills. Therefore, the researcher felt it was necessary to change the way student learn, replacing antiquated methods with teaching techniques that incorporate technology to improve learners' skills. In this study, the researcher seeks to understand the impact of software on students' skills in terms of instructional design in the selected subject at the college of education at Al-Baha University. Interactive educational software will be used to increase learners' understanding of instructional design. Therefore, the study centered on the lack of students' understanding of instructional design when taught by traditional methods, and why the use of software is needed as a new technique for implementing the course material.

The literature advocates the use of various degrees of multimedia software and discusses their impact on the learning environment. Faculty members need to employ e-learning techniques to improve learners' understanding of instructional design. The purpose of this study was to explore the impact of educational software on students' skills at the College of Education at Al-Baha University. Educational software was selected, and its procedures were adapted to produce the proposed General Instructional Design Model (ADDIE). A quasi-experimental method was also used on a sample of 60 students to study the impact of the independent variable (educational software) on the dependent variables (design skills) to test hypotheses of the study. Research Question

The study aimed to examine the following research question:

- How effective is interactive educational software on students' designing skills, specifically those students studying at the college of education? 
THE ASSUMPTIONS OF THE STUDY

- There is no statically significant difference in the level of $\alpha \leq 0.05$ between the mean scores of the experimental group (those using interactive educational software) and the control group (those using a traditional method) on the post achievement-tests as a result of the program.

- There is no statically significant difference in the level of $\alpha \leq 0.05$ between the mean scores of the experimental group (those using interactive educational software) and the control group (those using a traditional method) on the post observation checklisttests as a result of the program.

STUDY OBJECTIVES

In summary, the researcher aims to:

1. Measure the effectiveness of interactive educational software on students' design skills.

2. Test the significant differences between two study groups.

3. Design interactive educational software for the effective teaching of the concepts featured in the computer unit.

THE IMPORTANCE OF THE STUDY

- Help educators in choosing the most appropriate interactive educational software (interactive media) for their area.

- Be a starting point for further research that can be applied to different areas across a range of higher education institutes.

- Keep up with Saudi Arabia's Vision for 2030, which aims to transform classrooms into electronic learning environments through the computerization of the curriculum, dispensing with paper books.

\section{LIMITATIONS}

The study population: The research sample was conducted on students who registered on the course.

The subject: the course titled was "Use of computers in special education". The researcher selected the "The effectiveness of teaching by computers" unit to evaluate learners' skills, because the unit contained and great deal of data in the form of text.

Place of study: at the college of education at Al-Baha University duration was in the second semester of 2018-2019. 
مجلة كلية التربية بالإسماعيلية - العدد الواحد والأربعون - مايو 1^بـr

THE DEFINITION OF TERMS

EFFECTIVNESS AND ADDIE

According to Reiser and Dempsey (2007), the ADDIE model, which stands for analysis, design, development, implement, and evaluation, is a general process, and can be used to design a new model of any educational subject.

Operationally, it is an instructional design model based on five steps: analysis, design, development, implement, and evaluation.

Effectiveness is defined as the impact of the investigation as an independent element on the dependent factors, or an individual's need to obtain goals, feedback, and experience achievements (Jain and Singh, 2017).

Operationally, in this study, effectiveness refers to the statistical effect on the dependent variable, that is to say, the students' progress in learning the information featured in the unit titled 'Internet concepts' after using the independent variable (infographics) as a teaching method.

EDUCATIONAL SOFTWARE

According to Mukundan and Nimehchisalem (2008) an educational set contains a pile of lessons or courses involved to tests, teacher or learner guidelines available on multimedia through the Internet.

In short, it refers to software designed or used to facilitate teaching and learning. $O r$ it is a way of transferring theoretical or written data into visual information, which can be used to organize the lesson content to ensure that the information is attractive and learners understand it easily. Educational software can also be defined as a method to change complex data into information that can be understood easily and quickly by learners.

INTERACTIVE MEDIA

A new area of educational media is emerging to provide information to the public across a wide geographical area using digital computer-based systems via text, image, video, audio and animation. In short, it is a communication way in which the media output comes from users input.

INSTURCTIONAL DESIGN SKILLS

The practice of producing instructional experiences which make the acquisition of knowledge and skill more efficient, effective, and appealing. 


\section{LITERATURE REVIEW}

Most educational multimedia applications fall into the interactive graphical application category. These applications are multimedia tools which are capable of handling all forms of media design, as well as providing an interactive experience for the user. It also provides a very high level of language, explanatory scripting environment control navigation and enable user input. Although most applications provide these capabilities, some are better-suited to complex and interactive media than others.

Early history of educational software from 1940s to $1970 \mathrm{~s}$.

The use of computer programs in education and training environments dates to the early 1940s, when American scholars established flight simulators which used similarity computers to generate simulated onboard instrument data. Educational software was mostly implemented to support students and teachers during self-work and study at the time. Over the years, educational software was developed and has begun to replace teaching and textbooks. Nowadays, teachers can apply instructional support (educational software) to facilitate teaching for themselves and the learning process for students. The use of computers and software in education and training dates back to the early 1940s, when US researchers developed flight simulators that use analog computers to create simulation data for onboard devices.

Natsheh and Zahda (2019) study aimed to explore the use and evaluate of an educational computer software when implementing in teaching economics course at Palestine Polytechnic University. The study sample included 67 students. A quasi-experimental method was used in this study with a control that taught fractions by a traditional teaching method and experimental group by using educational software. The post-test results of the experimental group showed that the educational software improve the learning process.

Sevari and Falahi's study (2018) focused on the impact of Mathematical Educational Software on creativity and academic achievement among male students in the fifth grade of Azadegan elementary school in Tehran. The study design was a quasiexperimental method. The study sample was made up 60 learners that were separated into two groups: an experimental group, which was taught using educational software, and the control group, which was 
مجلة كلية التربية بالإسماعيلية - العدد الواحد والأربعون - مايو 1 I + r

taught by traditional methods. The measuring tool was an achievement test, as well as the Abedi Test of Creativity. The results showed that educational software has a positive effect on the study achievement and the creativity of male students in mathematics. In short, the findings suggest that teaching using Educational Software improves individuals' achievement in mathematics and creativity, because images make it easier for learners to understand data.

Lu (2017) aimed to construct a web-based hybrid learning model, path and platform for improve students' ability to understand language. The study tool included 1000 English words for the college students to memories. Most students gained a sense of accomplishment and became more interested in and enthusiastic about learning during software usage. Therefore, the study concluded that web-based software is very effective in helping college students' memories English words.

Atiker and Turan (2017) conducted a study that aimed to examine attitudes of students in elementary school toward educational software interfaces, and educational software screens principles. The study sample was made up of sixth grade learners at Şehit Öğretmen Hasan Akan Elementary School. The measuring tool was a survey. The results revealed that there was a statistically significant difference in text, graphic and screen layout programs. In addition, there was a significant difference between Eurosoft and the other software related to animation and color. The findings concluded that there were significant advantages of using educational software in learning.

Odadzic et al (2017) aim to discuss the effect of educational software usage and traditional teaching methods on biology lesson among high school students. The study sample were 173 learners in grade twelve at a high school in Zrenjanin, Serbia that were randomly distributed into control and experimental groups. The experimental group was taught biology, specifically mechanisms of heredity, using educational software, while the control group was taught by traditional methods. The study tools consisted of pre, post and retests. The results of the experimental group, revealed by the post-test and the re-test results, achieved significantly higher quantity and quality of knowledge in all three cognitive domains (knowing, understanding and reasoning) than the individuals from control group. It can be concluded that educational software has a more positive effect on increasing students' achievement in biology teaching than a traditional method. 
A study carried out by Sharifi et al (2017), aimed to design and validate educational software as an approach to develop individual's writing skills. The educational software used was an open-ended platform that motivated students to learn. The study sample included 31 teachers working in school located for the hearing-impaired in Iran. A mixed method design was conducted to obtain both quantitative and qualitative data. The results revealed that over $50 \%$ of participants indicated the software improved students' skills in all curricular areas. In conclusion, the design of the educational software was able to enhance the writing skills of the students. The study recommended conducting further research into how educational software affects students' performance.

Lysenko, Rosenfield and Dedic's (2016) study aimed to establish the impact of using emerging literacy by mathematics software in the classroom. The study sample included 234 students from 12 classes in grade one at a school in Canada. A quasi-experimental method was used in this study and the study tool was a bilingual interactive multimedia instruction tool. The post-test results of the experimental group showed that the participants of that group achieved significantly higher results in the standardized math test than the students from the control group. It can be concluded that emerging literacy in mathematics software has a more positive effect on developing students' achievement in mathematics than a traditional method.

Jurado, Petterson and Gomez's study (2016) focused to increase the use of educational software in higher education based on authors' experiences and the study. The data was conducted in four Latin American countries. The measuring tool was a survey and group discussion. The study sample was made up of 15 teachers who took a course about learning management system. The results showed that educational software has a positive effect on the social constructivist methods and learner-centered. In short, the findings suggest that teachers need to experience and embrace collaborative learning by Information and Communication Technologies in education.

Kocaman and Cumaoğlu (2014) aimed to measure the impact of using educational software (An individual games and educational software) used in teaching vocabulary about success and the strategy used for students. A quasi-experimental method was used in this study consisting of one group repeated measurements was applied. The posttest results of the experimental group showed the impact of educational software and games on the students' use of vocabulary learning 
مجلة كلية التربية بالإسماعيلية - العدد الواحد والأربعون - مايو 1 I. r

strategies. Two types of educational programs were used in the study, one of these programs (Dynamic English Vocabulary Instruction Program) was a kind of educational software used individually and the other consists of four different computer games. It can be concluded that emerging both types of software on vocabulary learning has a more positive effect on developing students' achievement. When the use of the strategy was analyzed by gender, it was found that compensation strategies were more used by male students than female students.

A study by Alhashimi (2014) looked at the use of technology in Oman when teaching Arabic, as well as the teachers' attitudes and suggestions. Twelve teachers took part and the results showed a high degree of technology use in the classroom. The findings also showed that there were also obstacles to applying the technology, however, such as learning how to use blackboard and designing programs. It is important to note that the use of educational technologies is common in Arabian countries, due to a cultural focus on research and science.

Study of Al-abrat (2011) study aimed to design software and its impact of on students' achievement in the classroom. It can be concluded that emerging software in class led to the students interact with educational software technology designed more than sense and thus increase academic achievement.

According to Serin (2011) the use of educational software and the provision of educational materials through computer technology enables learners to be able to build knowledge. In addition, it plays an active role in helping them to process and develop information, find alternative solutions, and develop skills process in problem solving.

Given our brain's ability to identify correlations, and patterns, studies show that visuals and graphic representations improve user cognition (Hullman, 2011).

Al-Mashrafe(2010) conducted a study, the aim of which was to explore the impact of the use of a general program to increase computer skills for students. The results was revealed the educational program was effective of developing computer skills. It can be concluded that educational software has a more positive effect on developing students' achievement in biology teaching than a traditional method.

According to Sahin and Turan (2009), whose study aimed to detect the impact of using technology on learning and teaching in a classroom environment, the results revealed only educationally sound teaching and suitable technologies guide to learning improvements. 
From students' views, the integration of technology in learning requires some strong skills.

Educational software should provide all learners with tools with support of which they can produce original ideas (Mukundan\& Nimehchisalem, 2008).

Hew and Brush (2007) examined the reason not all teachers incorporate technology into their education. Some resource obstacles are being solved by an increasing number of computers, software applications and faster, more consistent networks in schools. But teachers tend not to use technology if they are frustrated when it does not work properly or when there is a lack of technical support at their school. Teachers also point to limited time to review new technology tools and learn about tools they can use in teaching.

In the article titled "Technology uses and students' achievement: A longitudinal study", Lei and Zhao (2007) defined technology, and measured how much their students used it in 2003-2004. They defined technology as a piece, a product, and a tool, with the ability to solve certain issues connected to specific problems. For example, the program Microsoft Word has the capacity for literary structure, but only when used to write a paper containing certain contents will it solve problems or achieve goals. Most students $(81.4 \%)$ in the study used computers to do their homework. The next most common reason for computer use was to search for information for schoolwork (71.4\%), followed by emailing $(65.8 \%)$ surfing online for entertainment $(58 \%)$, chatting online $(51.1 \%)$ and working with specific software $(50.2 \%)$. About half of the students used computers to play games $(41.1 \%)$, and only $11.3 \%$ of students created websites. These results suggest that technology is largely used for inquiry and communication, rather than for expression and construction. In addition, it was found that students spent between 3-4 hours on their computer.

Designers of instruction can be found in several settings in institutions of higher education. Some universities hire instructional designers to serve instructors and students whether in the form of online or face-to-face support, as well as during online course development, improvement, and teaching. Some designers currently implement the ADDIE model as a general prescription to instructional design, while other use models such as backward design. Instructional designers in higher education must be elective in their use of ID theory and practice soft skills. 


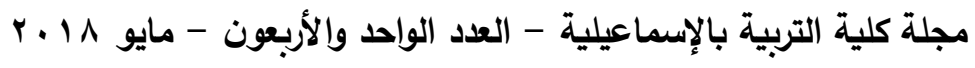

MATERIALS AND METHODS

RESEARCH DESIGN

The study belongs to the experimental design class (quasiexperimental) and is based on two groups to determine the influence of an independent variable (educational software) on a dependent variable (design skills), specifically improvement in the understanding of instructional design skills, and measured by an achievement test and observation checklist. The main study was conducted for the duration of 4 weeks. The educational software (interactive media), as well as the achievement test and observation checklist, were all created by the researcher of this study.

The study aimed to prove the theory that students' skills could improve through the use of interactive media in the classroom. A sample of learners from the college of education at Al-Baha University participated in classes that were taught using an educational software tool, while the other group were taught by a traditional method. A quantitative data collection process was selected to provide a general picture of the research problem, and the t-test method was used in this study to analyze the data. The goal of the descriptive design was focused on two aspects: educational software and skills.

A quasi experimental design approach was taken and included pre-test and post-test in the current study. The experimental group and control group consisted of students that had not dealt with educational software before and who had been taught by the researcher prior to the experiment. This experiment occurred during the academic year of 2018-2019.

\section{THE STUDY POPULATION}

The entire population of the College of education at Albaha University is 1,080 male learners and 1,443 female learners. Table 1 shows the design of both the experimental group and the control group, with the independent variable being the educational software. The dependent variable is the students' design skills.

\section{PARTICIPANTS}

The main study consisted of the experimental group, which was composed of 30 learners, who were taught using interactive educational software, while the control group was composed of 30 learners who 
were taught using a traditional method. Table 1 shows the experimental design.

Table (1) the experimental study

\begin{tabular}{|l|l|l|l|l|}
\hline Group & Pretest & Manipulating & Posttest & \\
\hline $\begin{array}{l}\text { The } \\
\text { experiment } \\
\text { (30 learners) }\end{array}$ & $\begin{array}{l}\text { Achievement } \\
\text { pretest and } \\
\text { observation } \\
\text { checklist(O1) }\end{array}$ & $\begin{array}{l}\text { Teaching using } \\
\text { educational } \\
\text { software(X1) }\end{array}$ & $\begin{array}{l}\text { Achievement } \\
\text { posttest and } \\
\text { observation } \\
\text { checklist } \\
\text { (O2) }\end{array}$ & $\begin{array}{l}\text { Deaching uscussion and } \\
\text { interpretation } \\
\text { of findings }\end{array}$ \\
\hline $\begin{array}{l}\text { The control } \\
\text { (30 learners) }\end{array}$ & & $\begin{array}{l}\text { method(X2) } \\
\text { metional }\end{array}$ & \\
\hline
\end{tabular}

\section{THE PROCEDURE OF THE STUDY}

A pilot study was conducted prior to the original study to ensure the reliability of this study instruments. The researcher conducted a pilot study with just 20 students to identify the time taken to conduct the main study and any potential obstacles. The results of the pilot study indicated that there were no obstacles. Following this, sixty learners from the College of Education were selected to take part in the main study. They were included in the study after being parity tested. The main study consisted of the experimental group, which was composed of 30 learners, who were taught using interactive educational software, while the control group was composed of 30 learners who were taught using a traditional method. Because a random distribution of participants in the research group was prohibited according to university management policies, the study was conducted among students. However, pre-experimental measures were incorporated to ensure equality between the research groups taking part in the study. The students' assignments for the first group included watching and discussing instructional design, then applying it using educational software, whereas the control group studied using a traditional method. At the end of the sessions, the test was administered to the participants in both groups as a post-test.

The steps in the process followed by the researcher are summarized below:

Reviewed the literature and previous studies related to the software approach,including its strategies, charts, and static, dynamic and interactive features.

- Identified the list of instructional design skills in education by examining the skills required, analyzing the content of unit, then 


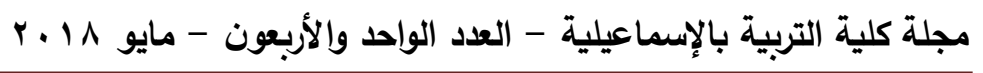

created a specification table of goals. This was followed by preparing the study tool (achievement test and observation checklist), interviewing college instructors, and then showing them the content analysis.

- Designed the study scenario, including the lesson materials containing interactive media.

- Divided the sample into two groups.

- Explained the effectiveness of teaching the computer studies unit using software as the teaching method for the experimental group and a traditional method for the second group, then applied the pre achievement test and observation checklist to measure the equalization of both groups, before administering the post-test to measure the significant difference between them on skills.

- Explained and analyzed the results.

- Selected the ADDIE design model to design an effective method of teaching the computer studies unit using educational software.

The first stage is Analysis

The literature on the subject of previous studies related to the use of interactive educational software and its impact was revised to prepare the theoretical framework of the study. Undergraduate students were selected as the target audience of the study and they watched and listened to software. The study was conducted in the computer lab, where there was access to the Internet. The effectiveness of teaching the computer studies unit was chosen as the focus of the study, because it contained a great deal of design skills that could be taught effectively using the educational software. The experimental group studied the unit with the aid of interactive media and the second control group with the aid of a traditional method.

The second stage is design

The educational software designed by the researcher contained four digital images and two videos (Adobe Illustrator) to attract learners attention to the software and aimed to aimed to teach 16 design skills. The data was presented clearly using codes, color and consistency. The scenario for application was drawn. The achievement test and observation checklist were based on recall, cognitive and application goals, and were comprised of 30 multiple choice questions 
to measure students' memory and comprehension. Then, a specification table was made including the number of questions to measure the impact of the software on students' design skills. Table 2 shows the reliability of the test.

Table (2) Test Reliability

\begin{tabular}{|llllll|}
\hline $\begin{array}{l}\text { Stability } \\
\text { coefficient(r1,1) }\end{array}$ & $\begin{array}{l}\text { Variation } \\
\text { grades(a2) }\end{array}$ & $\begin{array}{l}\text { of } \\
\text { deviation(a) }\end{array}$ & $\begin{array}{l}\text { Average } \\
\text { grades(m) }\end{array}$ & of & $\begin{array}{l}\text { Final } \\
\text { grade(n) }\end{array}$ \\
\hline $\mathbf{0 . 8 2}$ & $\mathbf{3 4 . 4 4}$ & $\mathbf{5 . 1 2}$ & $\mathbf{2 4 . 9 3}$ & $\mathbf{3 0}$ \\
\hline
\end{tabular}

The test results in Table 2 indicated that the reliability of the coefficient of the test was 0.82 , which in turn demonstrates that the test had a high level of stability. In terms of test validity, the researcher offered the test before using in to a group of specialists in teaching computer skills (I.T teachers) to calculate the test validity. There were five jury members to ensure the suitability of each paragraph of the test, its clarity, suitability of objectives and linguistic content.

The researcher ensured the test reliability by observing the students' performance and assessing them in each skill. The level of perfection was referred to as 30 and was awarded if the student completed the task perfectly, but they were given a mark of 0 in the case of complete inability to complete the task. The same process was repeated after one week. The Pearson correlation factor between the students' marks in the two previous observations was calculated as $\mathbf{0 . 8 8}$, indicating that the test was reliable and ready for application.

The Spearman correlation coefficient was calculated based on the scores of the sample between the total score of 10 comprehension level questions and 20 recall questions. Table 3 shows the results of the correlation coefficients.

Table 3. Correlation coefficients between the degree of each level and the total score of the achievement test.

\begin{tabular}{|l|l|l|}
\hline $\mathbf{N}$ & Level & $\begin{array}{l}\text { Correlation } \\
\text { coefficients }\end{array}$ \\
\hline 1 & Comprehension & $\mathbf{0 . 5 7 4}$ \\
2 & Recall & $\mathbf{0 . 6 3 0}$ \\
3 & Application & $\mathbf{0 . 6 4 3}$ \\
\hline
\end{tabular}

Table 3 indicates that the correlation coefficients between the score of each level and the total score of the test ranged between 0.574 and 0.630, which are statistically significant at a level of significance of less than 0.01. This finding indicates that the items of each test level are valid.

The third stage is development 


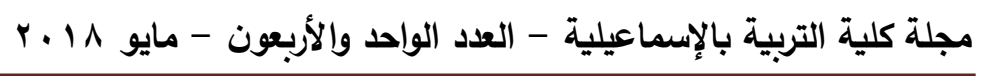

The researcher designed the software, which was titled" The effectiveness of teaching by computer", to teach 16 design skills. The researcher started the production and testing of the methodology used in the project, then showed it to a number of reviewers in the technology department to check the clarity on screen, its availability, and the process of building the software program. The researcher conducted a pilot study among 20 learners, who were not included in the sample for the main study, to check the availability, and to identify any obstacles and the time needed to conduct the main study (time spent answering for the first student+ time spent answering for the last student/2). The results of pilot study indicated there was no obstacle hindering the application of the program and that the time needed for each lecture was 1 hour. Then, the measurement tool was applied in the form of a post test, which recorded the data. The researcher then processing the data statistically, analyzed it, discussed the results, before making recommendations and suggestions in light of the results.

The pilot study consisted of 20 learners. The first 10 students finished the test within 25 minutes, while the other 10 finished the test within 30 minutes, so the average was 30 minutes. Cronbach's alpha value was 0.74 , which indicates it was of high validity. In order to determine the difficulties facing the researcher when applying the study, it is clear from that the coefficients of ease that the coefficients ranged from 0.73 to 0.50 and that the difficulty coefficients for the paragraphs ranged from 0.26 to 0.45 . The coefficient of ease or difficulty was approaching $\mathbf{5 5 \%}$.

The fourth stage is implementation

The researcher tested the educational software then revised it in terms of the availability of the software, the frequency of mistakes, and sources by peers, before applying it to the students. The researcher provided email and cellphone contact details in cases students had any queries related to how to use the software. The age of learners was between 20 and 24 years old. There were 60 male learners that participated in the study, all with the ability to deal with visual and auditory data. The subject being studied by them was use of computers in special education, and the specific focus of lesson featuring the software use was the "the effectiveness of teaching by computer"

The researcher analyzed the content of computer concepts unit (comprehension and recall goals). Table 4 shows the values of these transactions. 


\begin{tabular}{|l|l|l|}
\hline \multicolumn{2}{|c|}{ Table 4: Content analysis by the researcher } \\
\hline Content analysis of concepts & Number of items & $\begin{array}{l}\text { Points } \\
\text { difference }\end{array}$ \\
\hline 30 & 30 & $92 \%$ \\
\hline
\end{tabular}

Table 4 shows that the stability coefficient is $92 \%$, indicating the analysis was of a high stability. Based on the results of the analysis, the list of educational objectives was determined. The researcher determined the relative weights of the subjects, as well as the relative weights of the cognitive levels (remembering - understanding) by determining the number of questions related to the subject matter and determining the number of questions that were related to each level of knowledge in light of the list of objectives and cognitive concepts. The following is a presentation of the specification table for the cognitive test related to the concepts of educational technology.

Ease, difficulty, and discrimination coefficient: Ease, difficulty, and discrimination coefficients for test vocabulary: The corrected ease coefficient was calculated taking into account the effect of guesswork, difficulty, and the discrimination coefficient for each of the test items (according to the coefficient of corrected ease of estimation effect) through the results of the application of the test on the survey sample. To calculate the coefficient of ease and difficulty of the test as a whole, the coefficient of ease and difficulty, and the coefficient of discrimination were taken as: ease coefficient (1.2), coefficient of difficulty (3.0) and coefficient of discrimination (0.26).

The fifth stage is evaluation

To determine if the goals had been met, the pre and post-test were made to measure the learners' skills, taking into account feedback from learners. Then the data was recorded and monitored, and then the data was processed statistically, analyzed and the results were discussed. The researcher then made recommendations and suggestions in light of the results.

The achievement test and observation checklist were conducted to measure the study achievement and skills for the experimental and control groups.

RESULTS AND DISCUSSION

The researcher calculated the test normality of this study. The table (Table 5) shows the values of these transactions. 
مجلة كلية التربية بالإسماعيلية - العدد الواحد والأربعون - مايو 1 I + r

Table 5. Tests of normality

\begin{tabular}{|c|c|c|c|c|c|c|c|}
\hline \multirow[b]{2}{*}{ Group } & & \multicolumn{3}{|c|}{ Kolmogorov-Smirnov ${ }^{a}$} & \multicolumn{3}{|c|}{ Shapiro-Wilk } \\
\hline & & Mean & Df & Sig. & Mean & Df & Sig. \\
\hline \multirow{2}{*}{$\begin{array}{l}\text { Post- } \\
\text { test }\end{array}$} & Experimental & .250 & 29 & .024 & .886 & 29 & .034 \\
\hline & Control & .169 & 29 & $.300^{*}$ & .953 & 29 & .565 \\
\hline
\end{tabular}

TEST FOR NORMALITY

According to Warner (2008), the normality assumption is met when the residuals are normally distributed above the predicted dependent variable scores (students' achievements). The methods used to test the normality assumption were the Kolmogorov- Smirnov and Shapiro-Wilk tests. These tests were done to examine if the error terms were normally distributed (whereby a p-value of more than .05 means failure to reject the null hypothesis, indicating the error terms are normally distributed) (Warner, 2008). The normality assumption was violated because the residuals were not normally distributed according to the predicted dependent variable scores (students' achievements and learning engagement) and all variables were no less statistically significant than 0.05 , except the static predictor.

There is no statistically significant difference in the level of $(\alpha \leq 0.05)$ between the mean scores of the experimental group (those using interactive educational software) and the control group (those using a traditional method) on the pre and post achievement-test due to the software program.

A t-test for experimental and control groups was conducted to assure the equalization or similarity of the two groups in the pre-test by having the same experience in terms of their learning of "the effectiveness of teaching by computer" unit. The results are shown in Table (6).

Table 6 the equalization between the two groups (pre-test)

\begin{tabular}{|l|l|l|l|l|l|l|}
\hline Group & $\mathrm{N}$ & Mean & $\begin{array}{l}\text { Std. } \\
\text { Deviation }\end{array}$ & T value & Df & $\begin{array}{l}\text { Sig. (2- } \\
\text { tailed) }\end{array}$ \\
\hline Experimental & 30 & 15.14 & 1.689 & 1.712 & \multirow{2}{*}{5} & .067 \\
\hline Control & 30 & 14.27 & 1.445 & 1.712 & & \\
\hline
\end{tabular}

Table 6 shows there are no statically significant differences between the mean scores of the experimental group (those using interactive educational software) and the control group (those using a traditional method) on the pre-test of achievement. As $p \leq 0.05$, the null hypothesis is accepted. The results of the post-achievement test are shown in Table 7. 
Table (7) T-test between the two groups (post-test)

\begin{tabular}{|l|l|l|l|l|l|l|l|}
\hline Test & Group & $\mathrm{N}$ & Mean & $\begin{array}{l}\text { Std. } \\
\text { Deviation }\end{array}$ & $\mathrm{T}$ & Df & $\begin{array}{l}\text { Sig. (2- } \\
\text { tailed) }\end{array}$ \\
\hline $\begin{array}{l}\text { Post- } \\
\text { test }\end{array}$ & Experimental & $\mathbf{3 0}$ & $\mathbf{2 9 . 2 5}$ & $\mathbf{. 8 6 6}$ & \multirow{2}{*}{$\mathbf{1 9 . 8 7 5}$} & $\mathbf{5 8}$ & $\mathbf{. 0 0 0}$ \\
\cline { 2 - 5 } & Control & $\mathbf{3 0}$ & $\mathbf{1 9 . 2 1}$ & $\mathbf{1 . 7 0 5}$ & & \\
\hline
\end{tabular}

The results of the study analysis in Table 7 shows the results $(\mathrm{N}=30, \mathrm{p}<0.05)$ of the first experimental group of 30 students and the second experimental group of 30 students. In terms of the students' achievements, the experimental group (taught using software) reported a means of $\bar{x}=29.25$ in the posttest, with a standard deviation of $\sigma=$ .866, while the control group (taught using a traditional method) reported a mean score of $\bar{x}=19.21$ posttest, with a standard deviation of $\sigma=1.705$. After running a t-test on the experimental group, it showed that the difference between the pretest was $=15.14$ and posttest was $=$ 29.25, highlighting that there was an improvement in students' achievement and skills based on their results. $P=.000$. As $p<0.05$, the results indicated that there were statistically significant differences in the achievement mean groups, as shown in Table 6. The researcher attributed this to the impact of interactive educational software as learners increased their achievement, thus indicating it is more effective method than the traditional method used. Moreover, it was simple to explain skills, information, and maps attractively. The findings revealed that the experimental group did significantly better than the control group in terms of their achievement and skills. The results indicate that the use of interactive educational software can influence students' achievements in the subject of design skills. The findings are consistent with the previous studies on different subject material about the effectiveness of educational software on achievements, according to research by Saraya (2009); Liping (2017); and Serin (2011), the findings are consistent with the previous studies into the effectiveness of interactive educational software on achievement.

There was no statically significant difference in the level of $\alpha \leq 0.05$ between the mean scores of the experimental group (those using an interactive educational software) and the control group (those using a traditional method) in the pre and post observation checklist-test as a result of the program.

The t-test for the two independent samples was conducted to assure the equalization of the two groups in the pre-test (observation checklist). Table 8 shows the results of pre-test: 


$$
\text { مجلة كلية التربية بالإسماعيلية - العدد الواحد والأربعون - مايو } 1 \text { مأ. }
$$

Table 8 the equalization between the two groups (pre-measurement in observation checklist test).

\begin{tabular}{|l|l|l|l|l|l|l|}
\hline Group & $\mathrm{N}$ & Mean & $\begin{array}{l}\text { Std. } \\
\text { Deviation }\end{array}$ & T value & DF & $\begin{array}{l}\text { Sig. (2- } \\
\text { tailed) }\end{array}$ \\
\hline Experimental & 30 & 9.77 & 6.016 & -.506 & 58 & .452 \\
\hline Control & 30 & 7.50 & 5.706 & & 58 \\
\hline
\end{tabular}

Table 8 shows there are no statistically significant differences between the mean scores or grades of the experimental group (those using software) and the control group (those using a traditional method) on the pre-measurement in the observation checklist. As $p \leq$ 0.05 , the null hypothesis is accepted.

The t-test for the two independent samples was conducted using a scale to measure the observation checklist of the two groups in posttest. Table 10 shows the results of post-measurement:

Table 9 the post-measurement of the observation checklist

\begin{tabular}{|c|c|c|c|c|c|c|}
\hline Group & $\mathbf{N}$ & Mean & $\begin{array}{l}\text { Std. } \\
\text { Deviation }\end{array}$ & T value & Df & $\begin{array}{l}\text { Sig. (2- } \\
\text { tailed) }\end{array}$ \\
\hline experimental & 30 & 17.23 & 5.454 & 6.195 & \multirow[t]{2}{*}{58} & \multirow[t]{2}{*}{.000} \\
\hline Control & 30 & 10.86 & 2.514 & 3.173 & & \\
\hline
\end{tabular}

Table 9 shows the results $(\mathrm{N}=60, \mathrm{p}<0.05)$ in terms of the students' observation checklist measurement, the experimental group (taught using interactive educational software) reported a means of $\bar{x}=17.23$ in the posttest, with a standard deviation of $\sigma=5.454$, while the control group (taught using a tradiotnal method) reported a mean score of $\bar{x}$ $=10.86$ posttest, with a standard deviation of $\sigma=2.514$. After running a t-test on the experimental group, it showed that the difference between the posttest $=12.02$, highlighting that there was an improvement in students' observation checklist based on their results because of software usage. $P=.000$. As $p<0.05$, the results indicated that there were statistically significant differences in the observation checklist mean groups, as shown in Table 9. So, the findings also showed that the experimental group were significantly better than the control group in terms of their observation checklist grades. The results indicate that the use of interactive educational software can influence students' design skills. The researcher attributed this to the influence of interactive 
educational software on leading classroom discussion, as learners increase their skills. In short, interactive educational software provides opportunity for learners to share their experiences, work actively, search for information across different resources, interact with classmates by computer, and design instruction. These findings are consistent with other studies that have demonstrated that educational software can provide an increase in design skills (Lu, 2017; Atiker and Turan, 2017; Odadžić, Miljanović, Mandić,Pribićević and Županec, 2017).

The researcher calculated the measures of association of this study. Table 10 shows the values of these transactions.

The researcher calculated the measures of association of this study. Table 10 shows the values of these transactions.

Table 10 Measure of association

\begin{tabular}{|l|l|l|}
\hline Post test group & Eta & Eta Squared \\
\cline { 2 - 3 } & .976 & $\mathbf{. 9 3 4}$ \\
\hline
\end{tabular}

Table 10 shows the eta squared for the grade total of the posttest for the subject, which was the use of computers in special education, for the study sample (.934), which refers to grade changes in $93.4 \%$ of participants during the posttests for both study groups in favor of the first group that was taught using interactive educational software. CONCLUSION

The purpose of the study was to examine the effectiveness of educational software (interactive media) on students' design skills. The achievement tool and observation checklist were used to collect data by the researcher in this study. The results revealed that there were statistically significant differences at a level of $\alpha \leq 0.05$ between the mean scores of students from the experimental and control groups in the post achievement test and observation checklist, with the results in favor of the experimental group. Therefore, it is concluded that educational software is an effective tool for teaching and learning the module related to use of computers as part of the special education subject (the effectiveness of teaching by computer unit) at university. Therefore, the researcher recommends using educational software in university education and measuring its impact on students' design skills.

RECOMMENDATIONS FOR STUDY

- It is important to custom the design of the educational software to the teaching according to the subject. -

- As the sample of the current study only comprised of learners at AlBaha educational college at Al-Baha University in Saudi Arabia, future studies are needed to include learners from other colleges, to increase 


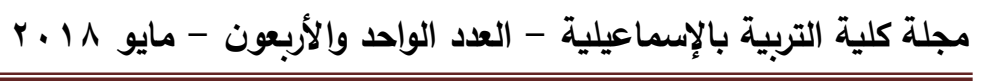

the sample size and thus make more accurate generalizations about the data.

- Encourage the administration and professors in every department of Al-Baha University to use educational software in their teaching.

SUGGESTIONS FOR FUTURE STUDY

- More studies are needed to investigate the effectiveness of educational software on learning skills in other subjects. As the sample of the current study only included male participants from the Al-Baha educational college at Al-Baha University in Saudi Arabia, future studies are needed to include females, as well as participants from other cities.

- A comparison of all types of web applications, specifically interactive media, is also needed to better understand the impact on design skills, achievement, and communication.

- A study of the effectiveness of software based on electronic games in the development of design skills among students. 
REFERENCES

Abdullah, N. (2017). Development of Interactive Software for Implementing the Science Process Skills in Science Primary School. International Journal of Academic Research in Business and Social Sciences, 7(6):728-744.

Alabrat, N.A.S. (2011). The Effect of Educational Software for Science in the Collection of the Seventh Grade Students of the Republic of Yemen,(Doctoral Dissertations), Damascus University Journal, 47.

Alhashimi,H.A.A.(2014). Reality the use of modern technology in teaching the course of Arabic language skills and obstacles to use at colleges of applied science in sultanate of Oman. International Specialized Educational Journal, 3(11), 83-100.

Al-Mashrafe, A. I. M.(2010) Effectiveness of the Efficiencies of Electronic Calendar with the Kindergarten Program in the Construction of the Electronic Bag to Work the Child Teacher, and its Impact on Computer Skills Development. Arab Journal for the Humanities, Kuwait University, the Council of Scientific Publications.

Atiker, B., \& Turan, B, O. (2017). Screen design principles of computer-aided instructional software for elementary school students. The Turkish Online Journal of Educational Technology, 16(2): 1-15.

Berthelsen, D., Brownlee, J., \&Lewis, G. B. (2002). Caregivers' epistemological beliefs in toddler programs. Early Child Development and Care 172, 503 - 516.

Hew, K. F. \& Brush, T. (2007). Integrating technology into K-12 teaching and learning: Current knowledge gaps and recommendations for future research. Educational Technology Research \& Development, 55(3), 223-52.

Hullman, J., Adar, E., \& Shah, P. (2011). Benefitting infovis with visual difficulties. IEEE Transactions on Visualization and Computer Graphics, 17(12), 2213-2222. doi:10.1109/TVCG.2011.175

Jain, N., \& Singh, N. (2017). Effects of infographic designing on image processing ability and achievement motivation of dyscalculia students. 45-53.

Jhurree, V. (2005). Technology integration in education in developing countries: Guidelines to policy makers. International Education Journal, 6(4): 467-483.

Jurado, R.G., Petterson, T., \& Gomez, A.R. (2016). Educational software and pedagogical development- success factors in 


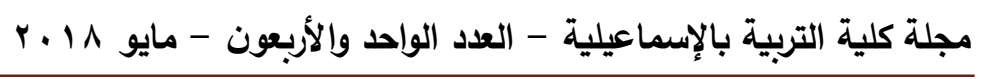

teachers training. In 18th Scientific Convention on Engineering ans Architecture CUJAE2016. Havana, Cuba: Proceedings.

Lei, J., \& Zhao, Y. (2007). Technology uses and student achievement: A longitudinal study. Science Direct, Computers and Education, 49: 284-296.

Liping, Lu. (2017). Study on the Effectiveness of Computeraided Software in Helping College Students Memorize English Words, International Journal of Emerging Technologies in Learning, 12(8):118-127.

Lu, L. (2017). Study on the Effectiveness of Computer-aided Software in Helping College Students Memorize English Word. IJET, 12(8): 118-127.

Lysenko, L., Rosenfield, S., \& Dedic, H. (2016). Using interactive software to teach foundational mathematical skills. Journal of Information Technology Education: Innovations in practice, 15:19-34.

Mndzebele, W. (2013). Challenges faced by school when introducing ICT in developing countries. International Journal of Humanities and Social Science Invention, 2(9): 1-4

Mukundan, J. \& Nimehchisalem, V. (2008). Educational software and English teaching courseware: Promising panaceas? Journal of Nepal English Language Teachers' Association, 12(2): 71-79.

Mukundan, J., \&Nimehchisalem, V. (2008).Educational Software and English Teaching Courseware: Promising Panaceas? Journal of NELTA, 13(1-2), 1-10.

Natsheh, M.N.,\&Zahda,F.H.(2019).The impact of using educational software on student fraction achievements case study: Economic course. International Journal of Information Science and Technology,3(2),2550-5114.

Odadžić,V.,Miljanović,

T., Mandić,D.,Pribićević,T.,\&Županec,V.(2017). Effectiveness of the Use of Educational Software in Teaching Biology. Croatian Journal of Education, 19(1): 11-43

Kocaman,O.,\&Cumaoğlu,G.K.(2014). The effect of educational software (denis) and games on vocabulary learning strategies and achievement. Education and Science,39(176),305-316.

Reiser, R. A., \& Dempsey, J. V.(2007). Trends and Issues in Instructional Design and Technology. Upper Saddle River, N.J.: Person Education, Inc. Boston, Massachusetts. 
Sahin, S., \& Turan, E. (2009). The effects and uses of educational technology in learning and teaching. Kastamonu Ĕ̈itim Dergisi, 17 (1): 321-330

Saraya, A. (2009). Educational technology and e-earning resources visual Concepts and practical applications, (2), Riyadh: AlRushd Library

Serin, O. (2011). The effects of the computer-based instruction on the achievements and problem-solving skills of the science and technology students. The Turkish Online Journal of Educational Technology, 10(1): 183-201.

Sevari, K., \& Falahi, M. (2018). The Effectiveness of Math Educational Software on Creativity and Academic Achievement. Psychology and behavioral science international journal, 8(4): 1-8

Sharifi, A., Arefi, M., Vajargah, K., \& Kakojoibari, A.(2017). Designing and validation of an educational software to improve writing skills of hearing-impaired students in primary schools. Aud Vest Res, 26(1): 14-20.

Tufte, E. (2001). Visual Explanations. Cheshire, CT: Graphics Press.

Vaughan, T. (2011). Multimedia: Making It Works. 8th Edition. New York: McGraw Hill, 2011.

Warner, R. M. (2008). Applied statistics from bivariate through multivariate techniques. Sage Publication, Inc. Los Angles, United States. 


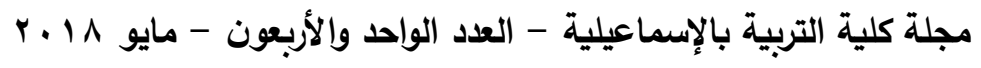

ABSTRACT

The study aimed to identify the effectiveness of designing interactive educational software to develop some instructional design skills and achievement among students of the College of Education, Al Baha University. The study used a quasi-experimental approach to prepare the literature framework and a measurement tool including an achievement test and observation checklist. The study sample consisted of 60 learners. The researcher used a t-test to measure the differences between the experimental group (studying using educational software) and the control group (studying by traditional methods). The results revealed that there was a significant difference in the in terms of the results from the experimental group taught by educational software, as they had an arithmetic average of $\mathbf{2 9 . 2 5}$ in the post achievement and 17.23 in the observation checklist. Therefore, the study recommends using Interactive Educational Software during university education and measuring the impact of developing some instructional design skills. Key Words: Multimedia; Development and Production; Abilities.

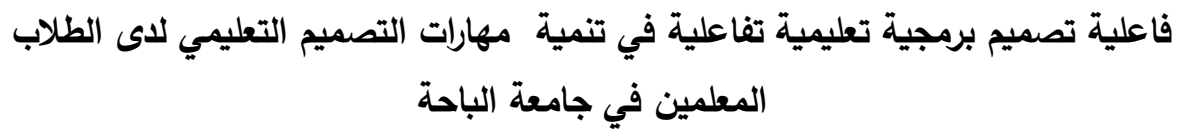

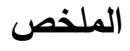

هافت الاراسة إلى الكثف عن فاعلية تصميم برنامج تعليمي تفاعلي لتنمية بعض

مهارات التصميم التعليمي والتحصيل لاى طلاب كلية التربية بجامعة الباحة.تم استخدام المنهج شبه التجرببي لإعداد الإطار النظري وأداتي القياس المتمثلة في اختبار تحصيلي وبطاقة الملاحظة، وتكونت عينة الاراسة من ، طالبا. استخدم الباحث اختبار ت لقياس الفرق بين المجموعتين التجريبية (درست بواسطة البرمجية التعليمية التفاعلية) والمجموعة الضابطة (درست بالطريقة التقليدية). وأسفرت نتائج الدراسة عن وجود فرق دال إحصائيا عند مستوى دلاية (الصالح المجموعة التجريبية التي درست بالتصميم القائم على البرامج التعليمية التفاعلية، حيث تراوح المتوسط الحسابي لها في الاختبار التحصيلي البعدي (25.92) وبطاقة الملاحظة(17.23). لذلك أوصت الدراسة باستخدام البرامج التعليمية التفاعلية في التعليم الجامعي وقياس مدى فاعليتها في تنمية بعض مهارات التصميم التعليمي. الكلمات المفتاحية: الوسائط المتعددة؛ التطوير والإنتاج؛ قدرات. 